Int. J. Morphol.,

30(1):188-195, 2012

\title{
Teaching Embryology Using Models Construction in Practical Classes
}

\author{
La Enseñanza de Embriología Usando la Construcción \\ de Modelos en las Clases Prácticas
}

*,**Tales Alexandre Aversi-Ferreira; ${ }^{* *}$ Roqueline A. G. M. F. Aversi-Ferreira; ${ }^{* * *}$ Guilherme Nobre Lima do Nascimento;
"Enkhjargal Nyamdavaa; ${ }^{* * *}$ Mariana Ferreira Araujo; ${ }^{* *}$ Peandra Paula Ribeiro; ${ }^{* *}$ Nattany Camila da Silva;
${ }^{* *}$ Lorraine Dias Brandão; ${ }^{* *}$ Lúcia Helena Almeida Gratão; ${ }^{* *}$ Tainá de Abreu; ${ }^{* *}$ Gabriel de Abreu Pfrimer;
${ }^{* *}$ Vanessa Vieira de Souza; ${ }^{* *}$ Nayane Peixoto Soares; Etsuro Hori \& *Hisao Nishijo

AVERSI-FERREIRA, T. A.; AVERSI-FERREIRA, R. A. G. M. F.; NASCIMENTO, G. N. L.; NYAMDAVAA, N.; ARAUJO, M. F.; RIBEIRO, P. P.; DA SILVA, N. C.; BRANDÃO, L. D.; GRATÃO, L. H. A.; ABREU, T.; PFRIMER, G. A.; SOUZA, V. V.; SOARES, N. P.; HORI, E. \& NISHIJO, H. Teaching embryology using models construction in practical classes. Int. J. Morphol., 30(1):188-195, 2012.

SUMMARY: Recently, the curriculum and the educational methodologies associated with health sciences courses are being reviewed and adapted. Pre-clinical sciences, such as anatomy and embryology are as well subjected to those changes. In human embryology courses it is common to use models to represent the different phases of development to facilitate learning, since the students can see and touch the models, obtaining knowledge by analogies. The purpose of the present study was to investigate if the construction of models by the students during practical embryology classes would improve or facilitate their learning. One year after the classes, 60 students answered a questionnaire with nine objective questions, including spaces for suggestions and observations. The student's responses suggested that the construction of models contributed to their learning.

KEY WORDS: Education; Education Nursing; Embryology; Health Science Education; Models; Morphology.

\section{INTRODUCTION}

Recently, the number of papers and reviews on health science education has increased considerably, mainly to medical (Cook \& Beckman, 2010) and nursing (Rozendo et al., 1999; De Santi, 1999; Stedile \& Friendlander, 2003; Silva \& Pedro, 2010; Almeida \& Soares, 2011; Backes et al., 2011) and has undergone detailed examination (Regan de Bere \& Mattick, 2010). Such emphasis is justified by the importance of medical care in the society. In addition, recent scientific findings and technological innovations accumulated a great amount of new knowledge in the health field (Aziz et al., 2002), especially in more advanced and specific areas of knowledge. For those reasons the courses related to health sciences must adapt their curriculum and educational methodologies.

Pre-clinical disciplines are essential for all health and biological science courses (Regan de Bere \& Mattick; Aziz et al.; Disnmore et al., 1999; Rizzolo, 2002; Biasutto et al., 2006). Among them, anatomy is considered to be the basis of morphological sciences. For that reason, throughout the history, this discipline has been viewed as a factual knowledge base that must be learned in its entirety (Disnmore et al., 1999). Recently, many health science schools are diminishing the curriculum time (Leung et al., 2006) and reducing the time allotted to traditional basic science disciplines (Aversi-Ferreira et al., 2010). In this context, the traditional morphology education based on topographical structural anatomy taught by didactic lectures and complete dissection of the body with personal tuition has been replaced by a multiple range of special study modules, problem-based workshops, computers, plastic models and many other teaching tools (Aziz et al.; Disnmore et al., 1999; Rizzolo; Biasutto et al.). In some centers, dissected cadaver-based anatomy is no longer taught (Biasutto et al.). Such changes may affect the efficiency of learning, which in turn might induce problems in health science education (Regan de Bere \& Mattick; Disnmore et al., 1999; Leung et al.; AversiFerreira et al.; Disnmore et al., 1993; Dyer \& Thorndike,

* System Emotional Science, Graduate School of Medicine and Pharmaceutical Sciences, University of Toyama, Toyama, Japan.

** Laboratory of Biochemistry and Neurosciences (Labine), Department of Nursing, Federal University of Goiás (UFG), Brazil.

*** Laboratory of Biochemistry and Neurosciences (Labine), Department of Nursing and Nutrition, Federal University of Tocantins (UFT), Brazil. 
AVERSI-FERREIRA, T. A.; AVERSI-FERREIRA, R. A. G. M. F; NASCIMENTO, G. N. L.; NYAMDAVAA, N.; ARAUJO, M. F.; RIBEIRO, P. P.; DA SILVA, N. C.; BRANDÃO, L. D.; GRATÃO, L. H. A.; ABREU, T.; PFRIMER, G. A.; SOUZA, V. V.; SOARES, N. P.; HORI, E. \& NISHIJO, H. Teaching embryology using models construction in practical classes. Int. J. Morphol., 30(1):188-195, 2012.

2000; Ferreira, 2003; Fornaziero \& Gil, 2003; McLachlan \& Regan de Bere, 2004; McLachlan et al., 2004; McLachlan \& Patten, 2006; Montemayor, 2006; Aversi-Ferreira et al., 2009; Mota et al., 2010).

The issues described above are not exclusive to anatomy, they encompass all basic health sciences disciplines (Aversi-Ferreira et al., 2008), including embryology (Freitas et al., 2008). The teaching methods used on both anatomy and embryology are very similar, because they deal with structures to support the understanding of their physiological functions (Aziz et al.). Embryology, however, has two additional features that add difficulties for its understanding (Freitas et al.): it deals with microscopic structures, which requires indirect observation, and it involves dynamic changes in the development of an embryo.

In classes for human embryology, it is common to use artificial models to represent the different phases of development (Freitas et al.). The use of this tool has the purpose of facilitating learning, since the students can see and touch the models, easily observing the three-dimensional aspects of the structures (Aziz et al.). This approach is particularly important in the case of the embryonic systems that, as stated above, undergo complicated transformations of form and shape throughout development. There are some commercial models for embryology classes, but they are too expensive and vulnerable to repeated manipulation (Freitas et al.). Therefore, some instructors have introduced an alternative method that includes the construction of models by the students during the classes (Aversi-Ferreira et al., 2009, 2008; Freitas et al.; Ferraz \& Terrazan, 2003). The first author has experience in teaching physiology and gross anatomy using regional dissection to medical students; an important data from such experience is that the construction of models during neuroanatomy and neurophysiology classes (Aversi-Ferreira et al., 2008) helps the students learning. We believe that the same results can be obtained in other basic disciplines, such as embryology.

The use of such analogies facilitates the understanding of scientific knowledge by bringing together two heterogeneous but similar domains (Ferraz \& Terrazan): an unfamiliar one (the problem to be explained), known as target, and a more familiar one, known as source (Ferraz \& Terrazan; Pena \& Andrade-Filho, 2010). In the case of embryology, the models are the source and the real embryo is the target. Learning, according to cognitive-constructivist theories, is a dynamic process that leads to the construction of knowledge; its process depends on the interaction between the subject and the environment, thus relying on the sense organs, mainly the visual and auditory ones. It occurs more effectively if the student experiences the information to be learned through several reception channels (auditory, visual, tactile and kinesthetic, for example) (Aversi-Ferreira et al., 2009,2010 ). In order to become knowledge, the information processed by the sensory systems must be stored as longterm memory, so it can be later retrieved (Aversi-Ferreira et al., 2010). Complex reasoning processes, which occur at the prefrontal cortex, are also necessary. Such processing is not simple, since it requires a lot of circuits and neuronal connections to associate the real world with the inside world of the students (Pena \& Andrade-Filho).

The use and construction of models could activate different reception channels, therefore facilitating learning. Thus, based on the analogies hypothesis, the purpose of the present study was to investigate if the construction of models by the students during embryology practical classes (innovative aspect) would improve or facilitate their learning. The results here described might include embriology into the scope of health sciences disciplines with new and more effective educational tools and methods.

\section{MATERIAL AND METHOD}

Practical classes involving the construction of embryonic models were implemented during the practical classes of two embryology courses, one for Nursing and other for Biological Sciences students, of two different universities. Each course was ministered by a different teacher. Both courses were ministered during 3 hours per week (2 hours of theory and 1 hour of practical classes), totalizing 30 hours in one semester. Both were also ministered together with basic histology (45 hours/semester) by the same teachers. However, basic histology was taught by the traditional method with theoretical classes combined with practical classes involving only microscopy and slice tissue observation.

During the embryology practical classes, the students were divided in groups from five to seven. They were advised to use textbooks and models prepared in advance by the teachers as guides, but the teachers were present to supervise the construction. The materials used to build the models were derived from sheets of old papers, sawdust from timbers, sand, plaster and glue, and their construction sequence was as follows. The papers were shredded, soaked and powdered to produce a spongy wet material from which the excess of water was removed. This material was then mixed with hands, blenders or other devices to equal parts of glue, sawdust powder (or sand, in some cases) and plaster, generating a homogeneous mass. After drying outdoors for about 48 hours at a temperature of about $25^{\circ} \mathrm{C}$, epoxi putty 
AVERSI-FERREIRA, T. A.; AVERSI-FERREIRA, R. A. G. M. F.; NASCIMENTO, G. N. L.; NYAMDAVAA, N.; ARAUJO, M. F.; RIBEIRO, P. P.; DA SILVA, N. C.; BRANDÃO, L. D.; GRATÃO, L. H. A.; ABREU, T.; PFRIMER, G. A.; SOUZA, V. V.; SOARES, N. P.; HORI, E. \& NISHIJO, H. Teaching embryology using models construction in practical classes. Int. J. Morphol., 30(1):188-195, 2012.

was used to make the details of the structures. Finally, the models were painted with washable paint.

The students made 20 models representing the embryonic stages from the fertilization of the oocyte II until the end of the third week of intrauterine life (end of the fetal period). They spent more time building models of the more complex structures, such as those representing organogenesis, embryo folding and neurogenesis.

One year after the end of the classes, 60 students (20 from nursing and 40 from biological sciences course) answered a semi-structured questionnaire (Fig. 1). All of them signed an informed consent document, following the specifications of the Resolution 196/96 of the Brazilian government (Brasil, Ministério Nacional da Saúde, 1996). The questionnaire had nine objective questions, including spaces for suggestions and observations. Statistical analysis was performed using the Statplus: mac 2009 software. Data from the questionnaires were submitted to a Normality test; those without a normal distribution were submitted to $\mathrm{c} 2$ tests, while those with normal distribution were submitted to t-tests to assess the similarity between the response frequencies of some parameters.

The evaluation of the students on histology and embryology courses was made through tests containing objective and discursive questions. For each course, $50 \%$ of the grades were randomly selected to calculate the average performance that was then compared by a t-test. Such comparison was done as a control, since they were ministered by the same teachers using different tools in the practical classes of each course. The comparison with traditional embryology courses ministered by different teachers was not made because many unpredictable factors, such as evaluation methods, could be different enough to generate misleading results. All the procedures were previously approved by an Ethics Committee.

\section{RESULTS}

The questionnaire analysis indicated that the majority of the students tended to choose one item for each question. The only exception was question number 3, where all possible responses could be simultaneously chosen (Fig. 1).

Figure 2 indicates the frequency of responses to each question item. Most of the students (41\%) evaluated that the construction of the models was what most caught their attention (answer [d] of Question 1 in Fig. 2) and 95\% of them stated that it improved their learning (answers [a] and [b] of Question 2 in Figs. 2 and 3). The questionnaire analysis also indicated that the students used several sources of information to build the models, since almost all possible items of question 3 were evenly chosen (Question 3, Fig. 2). Furthermore, in general, all or almost all of the members of each group contributed to the construction of the models (answers [a], [b], [c] and [d] of Question 4 in Fig. 2). In addition, most of the students rated their learning as "excellent" (25\%) or "good" (55\%) (answers [a] and [b] of Question 5 in Figs. 2 and 3) and 90\% of them stated that the construction of the models improved their learning (answer [a] of Question 6 in Figs. 2 and 3). The results also indicate that the students consulted textbooks or handouts not only for building the models (answers [a], [b] and [c] of Question 7 in Fig. 2) but also in other classes (answers [a], [b] and [c] of Question 8 in Fig. 2). Finally, all the students rated their participation during the classes as excellent $(50 \%)$ or good (50\%) (answers [a] and [b] of Question 9 in Fig. 2).

Figure 3 shows that a statistically significant majority of the students rated their learning as "excellent" or "good" (Question 5) and indicated that the model construction method improved and contributed to their learning (Questions 2 and 6) (c2 test to $\mathrm{p}<0.001$ ).

In addition, the students' average performance in embryology was significantly higher than in histology (Fig. 4) $(\mathrm{p}<0.05)$.

\section{DISCUSSION}

Recent scientific findings and technological innovations accumulated a great amount of new knowledge in the health science field (Aziz et al.). As a result, the apprentices must obtain more knowledge today than ten years ago, requiring changes in medical education that affect the basic sciences (Leung et al.), usually decreasing the curriculum time allotted to them (Rizzolo). These changes must also focus on new and alternative methodologies of teaching (Regan de Bere \& Mattick). In this context, the main purpose of this study was to investigate if the construction of models by the students during embryology classes would improve or facilitate their learning. According to the student's responses, they effectively learned the contents of the discipline (Question 5, Figs. 2 and 3) and the construction of models improved and contributed to their learning (Questions 2 and 3, Figs. 2 and 3). In addition, it was what most caught the attention of the majority of the students (Question 1, Fig. 2). Taken together, these data indicate that the construction of models is a good educational tool that helps to improve learning. In addition, those data 
AVERSI-FERREIRA, T. A.; AVERSI-FERREIRA, R. A. G. M. F.; NASCIMENTO, G. N. L.; NYAMDAVAA, N.; ARAUJO, M. F.; RIBEIRO, P. P.; DA SILVA, N. C.; BRANDÃO, L. D.; GRATÃO, L. H. A.; ABREU, T.; PFRIMER, G. A.; SOUZA, V. V.; SOARES, N. P.; HORI, E. \& NISHIJO, H. Teaching embryology using models construction in practical classes. Int. J. Morphol., 30(1):188-195, 2012.

\section{QUESTIONNAIRE}

Question 01

In the Embryology classes of the previous semester, what most caught your attention was:

( (a)The communication dynamics between teacher and students.

(b) The way the teacher explained the contents.

(c)Audiovisual aids used by the teacher.

(d) Models made by students.

(e) Others:

Question 02

In your opinion, the importance of building the models by yourself is that it:

(a) Improves learning because the student can perceive the three-dimensional aspects of the models.

(b) Improves learning because it allows the construction of mental images that are close to the real structures.

(c) Hinders learning because the students' attention is focused on the esthetic appearance of the pieces.

(d) Hinders learning because it does not contribute to the understanding of theoretical concepts.

(e) Others:

Question 03

You constructed the models based on:

(a) The explanation given by the teacher in classroom.

(b) The literature reviewed outside the classroom.

(c) Pictures from textbooks and atlases.

(d) Other models.

(e) More than one of the alternatives mentioned above.

Which?

(f) In all the alternatives mentioned above.

(g) Other:

Question 04

What was the group's involvement in making the model?

(a) All members participated effectively.

(b) Only some of the members participated effectively.

(c) There was a division of tasks and each member did their part independently.

(d) There was division of labor and all contributed to what the fellow was doing.

(e) There was no involvement, I made the model alone.

(f) I did not participate actively in the work of my group.

Question 5

How do you rate your learning in embryology?

(a) Excellent

(b) Good

(c) Regular

(d) Poor

Question 06

The methodology of constructing models from recyclable material contributed to improve your learning?
(a) Yes
(b) No

Question 07

How often did you consult books or handouts for making the models?
(a) Always
(b) Frequently
(c) Occasionally
(d) Never

Question 08

How often did you consult books and/or handouts in other classes?
(a) Always
(b) Frequently
(c) Occasionally
(d) Never

Question 09

How do you rate your participation during the classes in which the models were built?
(a) Excellent
(b) Good
(c) Regular
(d) Poor

Fig. 1. Questionnaire answered by the students. 
AVERSI-FERREIRA, T. A.; AVERSI-FERREIRA, R. A. G. M. F.; NASCIMENTO, G. N. L.; NYAMDAVAA, N.; ARAUJO, M. F.; RIBEIRO, P. P.; DA SILVA, N. C.; BRANDÃO, L. D.; GRATÃO, L. H. A.; ABREU, T.; PFRIMER, G. A.; SOUZA, V. V.; SOARES, N. P.; HORI, E. \& NISHIJO, H. Teaching embryology using models construction in practical classes. Int. J. Morphol., 30(1):188-195, 2012

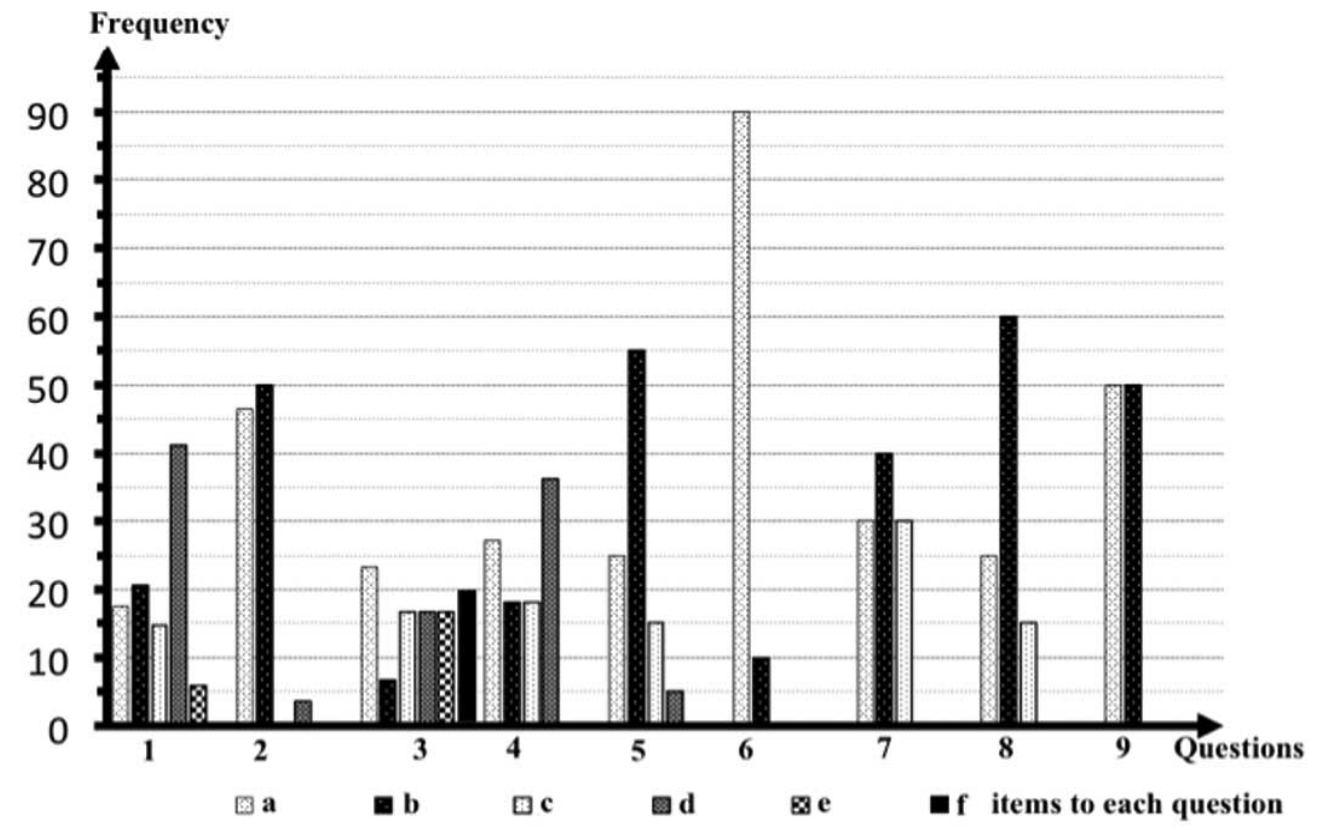

Fig. 2. Frequency of responses to each question item from questionnaire.

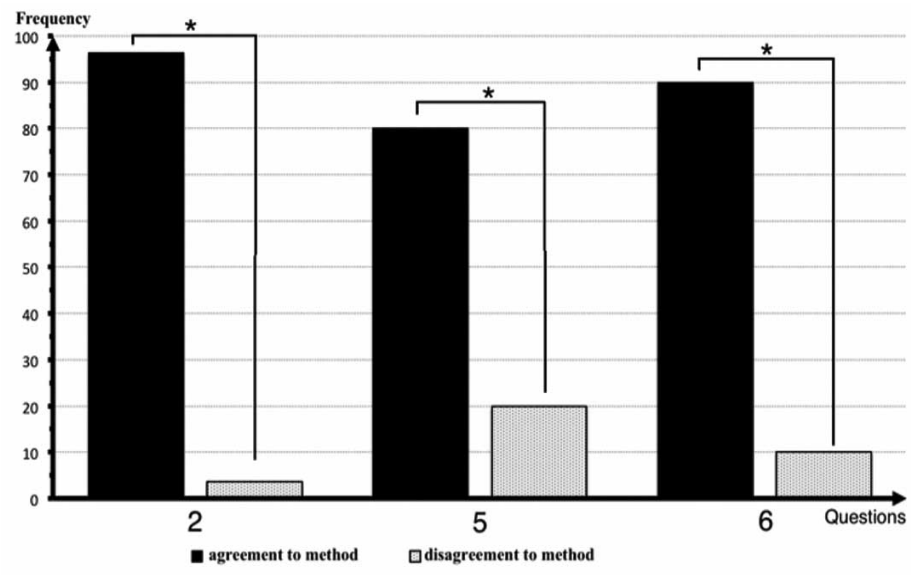

Fig. 3. Evaluation of the method's contribution to the learning process. The bar indicates percentage of students that rated their learning according data from questionnaires. The independency $\mathrm{c} 2$ test $[\mathrm{p}<0.001]$ demonstrated significant differences between agreement and disagreement use of models construction in embriology classes [*].

are also in accordance with the human psychological perspective, which values the direct interaction with the environment to acquire knowledge and self-realization (De Santi; Noronha et al., 2002) in a continuous way. This method is also in accordance with the new curriculum directions for nursing of the Ministry of Education and Culture (MEC) in Brazil (Ministério da Educação e Cultura, 2001): "learning to learn, learning to be, learning to do, learning to live together and learning to know", and similar methodologies teaching using metacognitive process (Stedile \& Friendlander) could be included in all fields.

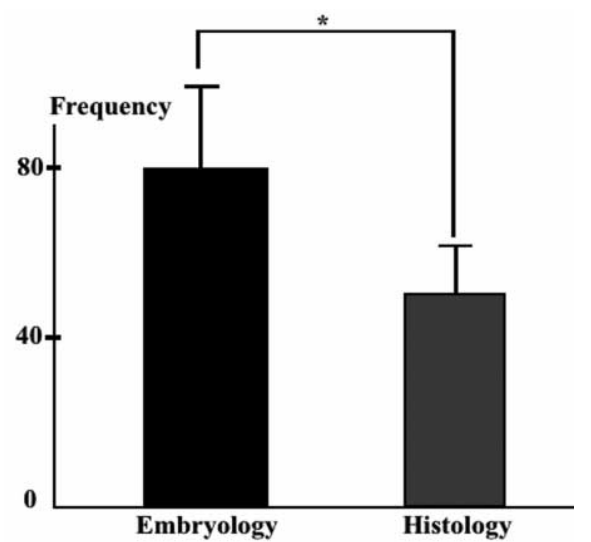

Fig. 4. Students mean performance in embryology and histology. To $\mathrm{p}<0.05$ (t-test) was observed significant differences among performances [*].

This work also intended to link the traditional explanatory theoretical classes with practical activities, replacing the simple knowledge transmission by a process of integrated investigation and increasing the participation of students in the construction of their own knowledge, in accordance with post-modern education and metacognition processes. The responses given on questions 3, 7 and 8 provide evidence that the methodology described in this work achieved such purposes. Furthermore, the results indicate that the students considered that all or almost all of their group colleagues engaged on the construction activities 
AVERSI-FERREIRA, T. A.; AVERSI-FERREIRA, R. A. G. M. F.; NASCIMENTO, G. N. L.; NYAMDAVAA, N.; ARAUJO, M. F.; RIBEIRO, P. P.; DA SILVA, N. C.; BRANDÃO, L. D.; GRATÃO, L. H. A.; ABREU, T.; PFRIMER, G. A.; SOUZA, V. V.; SOARES, N. P.; HORI, E. \& NISHIJO, H. Teaching embryology using models construction in practical classes. Int. J. Morphol., 30(1):188-195, 2012.

(Question 4, Fig. 2) and that $100 \%$ of students rated their own participation as "good" or "excellent" (Question 9, Fig. 2). Overall, these results indicate that the approximation between "source" and "target" was possible by the association of strategies from the postmodern paradigm with the use of analogies (Ferraz \& Terrazan; Pena \& AndradeFilho) and manual activities to construct the models. In addition, they indicate that the students worked well in group. In general, group learning facilitates not only the acquisition of knowledge but also several other desirable attributes, such as communication, teamwork, problem solving and information sharing skills, as well as respect for others opinions (De Santi; Webb, 1982).

Traditionally, the educational system is based on methods that assume that the teacher is the "absolute lord of knowledge", whose role is to explain to the students the information to be transmitted (Mota et al.; Freitas et al.). In health sciences, the teachers tend to prepare their classes based on this traditional method (Rozendo \& Casagrande). In this scenario, the student is simply a container that must be filled in with knowledge. On the other hand, according to the postmodern paradigm and metacognition process, the teacher must choose procedures that are suitable for the construction of knowledge by the students (Aversi-Ferreira et al., 2009). According to this view, the students actively participate on the teaching-learning process and become a fundamental agent of their own learning, which is fundamental, since it is suggested that self-knowledge and selfreflection help the learning (Noronha et al.). This new paradigm is not a simple deny of the traditional and hegemonic system, but an adaptation and renovation of it, with the development of new ways to approach the students. Such ideas are especially important for factual disciplines, such as anatomy (Regan de Bere \& Mattick) and embryology. Accordingly, during the models construction classes, the teacher acted as a mediator, promoting exchanges conditions between the students and improving the teacher-student dialogue and giving autonomy to the students solve problems, i.e. to choose the best way to construct models and obtain knowledge (Silva \& Pedro).

The use of a constructivist method associated with postmodern paradigms generates an effective relation between teaching and learning. This effect, observed in previous studies (Aversi-Ferreira et al., 2008, 2009; Freitas et al.), was also observed in the present work, because the learning is more effective when it is possible to experience the content/knowledge of objects using various channels of perception and information processing (Aversi-Ferreira et al., 2009; Pena \& Andrade-Filho). The use of analogies through the construction of models during the learning process was a successful strategy to link the gap between what the student already knew and what he should learn (Pena \& Andrade-Filho).

Moreover, each group had extra class activities, since they gathered together after class to finish the construction of the models. Student reports suggest that their family members and friends helped them with ideas to facilitate the construction of the models, such as using a laundry tub to generate the homogeneous mass (see Material and Method). These results are in accordance with many purposes of education (Miranda \& Barroso, 2004), like supportive education, with the articulation of knowledge in the community, school and environment, through collective work and could to generate approach between gap in nursing education and practice (Fulmer et al., 2011). Students reports suggests that such purposes

The results here discussed do not rule out the necessity of traditional theoretical classes that provide fundamental basic knowledge and motivation to the students, since the formal exposition of contents, when conducted correctly by teacher, is necessary to guide the students thus facilitating learning. Therefore, we consider that an association between theoretical expositions and new methodologies, such as models constructing, is important to help the students to develop social relationships, self learning and autonomic problem solving, which is not a trivial task (Stedile \& Friendlander) since it requires the integration between health education and pedagogic practices (Almeida \& Soares). In fact, we agree with others authors that if the knowledge is increasing then the curriculum time should also increase (Rizzolo; Aversi-Ferreira et al., 2010). The anatomy disciplines, including gross anatomy, histology, cytology and embryology, are fundamental to generate a good knowledge basis for the health professionals, so the time assigned to those disciplines is especially important.

It is important to point here that the discipline of embryology was conjugated with histology, but the models were only built during the embryology classes. The histology classes consisted only of theoretical and practical classes with observations on microscopy. The grades of the students were approximately $25 \%$ higher in the embryology tests, compared with the histology tests grades $(\mathrm{p}<0.001)$ (Fig. 4). This data supports the reliability of the students' answers and the findings here described, indicating that the emphasis on pre clinical education improvement remains on the development of more efficient teaching methodologies to support the teacher work (Regan de Bere \& Mattick). Furthermore, it seems that the use of new perspectives and methodologies, such as the construction of cells and tissues models, might improve the students learning during histology classes. 
AVERSI-FERREIRA, T. A.; AVERSI-FERREIRA, R. A. G. M. F.; NASCIMENTO, G. N. L.; NYAMDAVAA, N.; ARAUJO, M. F.; RIBEIRO, P. P.; DA SILVA, N. C.; BRANDÃO, L. D.; GRATÃO, L. H. A.; ABREU, T.; PFRIMER, G. A.; SOUZA, V. V.; SOARES, N. P.; HORI, E. \& NISHIJO, H. Teaching embryology using models construction in practical classes. Int. J. Morphol., 30(1):188-195, 2012

In neural aspects, it is possible to state that the construction of the models during the learning generates a long-term memory from the many associations required to perform the task. Indeed, learning is more effective when the student uses various reception channels (Aversi-Ferreira et al., 2009, 2010) because the stimulus is reinforced as shortterm memory, generating the stock in long-term memory and increasing the activation of the pre-frontal cortex (Bunge et al., 2005), enabling the association between the real world and the inside world of the student (Pena \& Andrade-Filho) i.e. proximity between "sources" and "targets". This hypothesis, however, needs to be further explored by behavioral and physiological tests.

In conclusion, these data indicate that (1) the postmodern paradigm in practical classes associated with the use of motivational theoretical classes and analogies is an effective method to generate proximity between the "source" and the "target" and can be applied to teach embryology; (2) the teaching-learning were not dissociated in the model construction, which was more effective than the traditional method in terms of mean performance, and; (3) this technique can be an instrument to improve teaching/learning in other disciplines, such as morphology in general.

\section{ACKNOWLEDGMENTS}

This work was supported partly by CREST (Core Research for Evolutional Science and Technology), JST (Japan Science and Technology Agency), Japan, JSPS (Japan Society for the Promotion of Science) Asian Core Program, and the Ministry of Education, Science, Sports and Culture, Grant-inAid for Scientific Research (A) (22240051); and by CNPq (National Council of Technology and Development - Brazil). The funders had no role in study design, data collection and analysis, decision to publish, or preparation of the manuscript.

AVERSI-FERREIRA, T. A.; AVERSI-FERREIRA, R. A. G. M. F.; NASCIMENTO, G. N. L.; NYAMDAVAA, N.; ARAUJO, M. F.; RIBEIRO, P. P.; DA SILVA, N. C.; BRANDÃO, L. D.; GRATÃO, L. H. A.; ABREU, T.; PFRIMER, G. A.; SOUZA, V. V.; SOARES, N. P.; HORI, E. \& NISHIJO, H. La enseñanza de embriología usando la construcción de modelos en las clases prácticas. Int. J. Morphol., 30(1):188-195, 2012.

RESUMEN: Recientemente, el plan de estudios y las metodologías educativas asociadas a los cursos de ciencias de la salud están siendo revisados y adaptados. Ciencias pre-clínicas tales como la Anatomía y la Embriología son también sometidas a cambios. En los cursos de Embriología Humana, es común el uso de modelos para representar las diferentes fases del desarrollo, y así facilitar el aprendizaje, ya que los estudiantes pueden ver y tocar los modelos, así se realiza la obtención de conocimientos por medio de analogías. El propósito del presente estudio fue investigar si la construcción de modelos por parte de los estudiantes, durante las clases prácticas de Embriología, mejora o facilita su aprendizaje. Después de un año, 60 estudiantes respondieron a un cuestionario con nueve preguntas objetivas, incluidos los espacios para sugerencias y observaciones. De acuerdo con las respuestas de los estudiantes, la construcción de modelos han contribuido a su aprendizaje.

PALABRAS CLAVE: Educación, Educación en Enfermería; Embriología; Educación en Ciencias de la Salud; Modelos; Morfología.

\section{REFERENCES}

Almeida, A. H. \& Soares, C. B. Health Education: Analysis of its Teaching in Undergraduate Nursing Courses. Rev. Latino-Am. Enfermagem, 19:614-21, 2011.

Aversi-Ferreira, T. A.; Lopes, D. B.; Reis, S. M. M.; Abreu, T.; Aversi-Ferreira, R. A. G. M. F.; Vera, I. \& Lucchese, R. Practice of dissection as teaching methodology in anatomy for nursing education. Braz. J. Morphol. Sci., 26:151-7, 2009.

Aversi-Ferreira, T. A.; Monteiro, C. A.; Maia, F. A.; Guimarães, A. P. R. \& Cruz, M. A. Neurophysiology study associated with three-dimensional models constructed during the learning. Biosci. J., 24:98-103, 2008.

Aversi-Ferreira, T. A.; Nascimento, G. N. L.; Vera, I. \& Lucchese,
$\mathrm{R}$. The practice of dissection as teaching methodology in anatomy applied to medical education. Int. J. Morphol., 28:26572,2010

Aziz, M. A.; Mckenzie, J. C.; Wilson, J. S.; Cowie, R. J.; Ayeni, S. A. \& Dunn, B. K. The human cadaver in the age of biomedical informatics. Anat. Rec., 269:20-32, 2002.

Backes, V. M. S.; Moyá, J. L. M. \& Prado, M. L. The Construction Process of Pedagogical Knowledge among Nursing Professors. Rev. Latino-Am. Enfermagem, 19:421-8, 2011.

Biasutto, S. N.; Caussa, L. I. \& del Rio, L. E. C. Teaching anatomy? Cadavers vs. computer. Ann. Anat., 188:187-90, 2006. 
AVERSI-FERREIRA, T. A.; AVERSI-FERREIRA, R. A. G. M. F.; NASCIMENTO, G. N. L.; NYAMDAVAA, N.; ARAUJO, M. F.; RIBEIRO, P. P.; DA SILVA, N. C.; BRANDÃO, L. D.; GRATÃO, L. H. A.; ABREU, T.; PFRIMER, G. A.; SOUZA, V. V.; SOARES, N. P.; HORI, E. \& NISHIJO, H. Teaching embryology using models construction in practical classes. Int. J. Morphol., 30(1):188-195, 2012.

Brasil, Ministério Nacional da Saúde. Conselho Nacional de Saúde. Resolução 196/96 sobre pesquisa envolvendo seres humanos. Bioética, 4:15-25, 1996.

Bunge, S. A.; Wendelken, C.; Badre, D. \& Wagner, A. D. Analogical reasoning and the pre-frontal cortex: Evidence for separable retrieval and integration mechanisms. Cereb. Cortex, 15:23949, 2005

Cook, D. A. \& Beckman, T. J. Reflections on experimental research in medical education. Adv. Health Sci. Educ. Theory Pract., 15:455-64, 2010.

De Santi, M. C. O repensar dos conteúdos escolares: os processos de transmissão, aquisição e construção dos conhecimentos. Rev. Latino-am. Enfermagem, 7:113-4, 1999.

Dinsmore, C. E.; Daugherty, S. \& Zeitz, H. J. Teaching and learning gross anatomy: Dissection. Prosection, or both of the above? Clin. Anat., 12:110-4, 1999.

Disnmore, C. E.; Paul, H. \& Sweet, F. A core anatomy program for the undergraduate medical curricullum. Acad. Med., 73:5856, 1993.

Dyer, G. S. \& Thorndike, M. E. Quidne mortui vivos docent? The evolving purpose of human dissection in medical education. Acad. Med., 75:969-79, 2000.

Ferraz, D. F. \& Terrazan, E. A. Uso espontâneo de analogias por professores de biologia e o uso sistematizado de analogias: que relação?. Ciência \&Educação, 9:213-27, 2003.

Ferreira, M. L. S. M. Avaliação no processo ensino-aprendizagem: uma experiência vivenciada. Rev. Bras. Educ. Med., 27:12-9, 2003 .

Fornaziero, C. C. \& Gil, C. R. R. Novas tecnologias aplicadas ao ensino da anatomia humana. Rev. Bras. Educ. Med., 27:141-6, 2003

Freitas, L. A. M.; Barroso, H. F. D.; Rodrigues, H. G. \& AversiFerreira, T. A. Construction of embryonic models with recycled material for didactic using. Biosci. J., 24:91-7, 2008.

Fulmer, T.; Cathcart, E.; Glassman, K.; Budin, W.; Naegle, M. \& Devanter, N. V. The Attending Nurse: An Evolving Model for Integrating Education and Practice. Open Nurs. J., 5:9-13, 2011.

Leung, K. K.; Lu, K. S.; Huang, T. S. \& Hsieh, B. S. Anatomy Instruction in Medical Schools: Connecting the Past and the Future. Adv. Health Sci. Educ. Theory Pract., 11:209-15, 2006.

McLachlan, J. C.; Bligh, J.; Bradley, P. \& Searle, J. The use of cadavers in anatomy teacher. Med. Educ., 38(4):418-24, 2004.

McLachlan, J. C. \& Patten, D. Anatomy teaching: ghosts of the past, present and future. Med. Educ., 40:243-53, 2006.
McLachlan, J. C. \& Regan de Bere, S. How we teach anatomy without cadavers. Clin. Teach., 1:49-52, 2004.

Ministério da Educação e Cultura. Diretrizes Curriculares Nacionais do Curso de Graduação em Enfermagem. Brasília, Ministério da Educação e Cultura, 2001.

Miranda, K. C. L. \& Barroso, M. G. T. Contribuição de Paulo Freire a prática e educação crítica em enfermagem. Rev. Latino-am. Enfermagem, 12:631-5, 2004.

Montemayor, F. B. G. El significado de la práctica de disección para los estudiantes de Medicina. Int. J. Morphol., 24:575-80, 2006.

Mota, M. F.; Mata, F. R. \& Aversi-Ferreira, T. A. Constructivist pedagogic method used in the teaching of human anatomy. Int. J. Morphol., 28:369-74, 2010.

Noronha, A. B.; Sophia, D. \& Machado, K. Formação Profissional em Saúde. RADIS comunicação FIOCRUZ, 3:11-7, 2002.

Pena, G. P. \& Andrade-Filho, J. S. Analogies in medicine: valuable for learning, reasoning, remembering and naming. Adv. Health Sci. Educ. Theory Pract., 15:609-19, 2010.

Regan de Bere, S. \& Mattick, K. From anatomical competence to complex capability. The views and experiences of UK tutors on how we should teach anatomy to medical students. Adv. Health Sci. Educ. Theory Pract., 15:573-85, 2010.

Rizzolo, L. J. Human Dissection: An approach to interweaving the traditional and humanistic goals of medical education. Anat. Rec., $269: 242-8,2002$

Rozendo, C. A. \& Casagrande, L. D. R.; Schneider, J. F. \& Pardini, L. C. Uma análise das práticas docentes de professores universitários da Área de saúde. Rev. Latino-am. Enfermagem, 7:15-23, 1999.

Silva, A. P. S. \& Pedro, E. N. R. Autonomy in Nursing Students' Process of Knowledge Construction: The Educational Chat as a Teaching Tool. Rev. Latino-Am. Enfermagem, 18:210-6, 2010.

Stedile, N. L. R. \& Friendlander, M. R. Metacognição e ensino de enfermagem: uma combinação possível?. Rev. Latino-am. Enfermagem, 11:792-9, 2003

Webb, N. M. Peer interaction and learning in cooperative small groups. J. Educ. Psychol., 74:642-55, 1982.

Correspondence to:

Tales Alexandre Aversi-Ferreira

System Emotional Science Graduate School of Medicine and Pharmaceutical Sciences University of Toyama

2630 Sugitani, Toyama 930-0194 JAPAN

Email: aversiferreira@gmail.com
Received: 05-11-2011

Accepted: 30-12-2011 